\title{
Tingkat Partisipasi Masyarakat dalam Pengelolaan Hutan Nagari di Sumatera Barat
}

\section{The Level of Community Participation in Management of Hutan Nagari in West Sumatera}

\author{
Nala Sari Tanjung ${ }^{1}$, Dwi Sadono², Cahyono Tri Wibowo ${ }^{2}$ \\ ${ }^{1}$ Program Studi Komunikasi Pembangunan Pertanian dan Pedesaan, Fakultas Ekologi Manusia, \\ Institut Pertanian Bogor, Bogor \\ ${ }^{2}$ Departemen Sains Komunikasi dan Pengembangan Masyarakat, Fakultas Ekologi Manusia, \\ Institut Pertanian Bogor, Bogor
}

\begin{abstract}
Participation is a key feature in a sustainable development, including forest management with the principle of sustainable village based on community empowerment. This study aims to 1) describe the level of community participation in managementof Hutan Nagari and 2) analyzethe relation of community participation with a sustainable management of Hutan Nagari. This study was designed using anexplanative survey method for connecting and comparing. Locations were selected purposively in LPHN Sungai Buluh and LPHN Paru. The management of Hutan Nagari in Sungai Buluh and Paru is already sustainable, supported by some factors and participation of community members in management of Hutan Nagari.The involvement in all activities of managementwas a major factor that support a sustainable forest management in village communities. Members of LPHN Sungai Buluh participate adequately in management of Hutan Nagari, whereas those of LPHNParu participate less. The inadequate involvement of community members in LPHNoccured in the management activities consisting of planning, delimitation of the operation areas, and monitoring and evaluation. This should be minimized by involving all community members in any management activities, as well as giving opportunity to members to reflect their involvement on a collective action through the implementation of joint activities.
\end{abstract}

Keywords: Hutan Nagari, participation, sustainable development, management

\begin{abstract}
Abstrak
Partisipasi merupakan fitur kunci dalam pembangunan berkelanjutan, termasuk dalam pengelolaan Hutan Nagari dengan azas lestari yang berbasis pada pemberdayaan masyarakat. Penelitian ini bertujuan untuk: 1) Mendeskripsikan tingkat partisipasi masyarakat dalam pengelolaan Hutan Nagari; 2) Mengalisa hubungan partisipasi masyarakat dengan pengelolaan Hutan Nagari secara berkelanjutan. Penelitian ini didesain menggunakan metode survei eksplanatif untuk menghubungkan dan membandingkan. Lokasi penelitian dipilih secara purposif di LPHN Sungai Buluh dan LPHN Paru. Pengelolaan Hutan Nagari di Sungai Buluh dan Paru sudah berkelanjutan yang didukung oleh faktor-faktor dukungan dan partisipasi anggota masyarakat dalam pengelolaan Hutan Nagari. Keterlibatan masyarakat anggota dalam seluruh aktivitas pengelolaan, yaitu perencanaan, penetapan batas areal kerja, pelaksanaan kegiatan, dan monitoring evaluasi, merupakan faktor utama yang mendukung pengelolaan Hutan Nagari secara berkelanjutan oleh masyarakat. Anggota masyarakat pengelola di Hutan Nagari Sungai Buluh cukup berpartisipasi dalam pengelolaan Hutan Nagari, sedangkan di Hutan Nagari Paru kurang berpartisipasi. Kurangnya keikutsertaan anggota masyarakat dalam pengelolaan Hutan Nagari terjadi karena anggota masyarakat kurang dilibatkan dalam kegiatan pengelolaan. Hal ini harus diminimalisir dengan melibatkan seluruh anggota masyarakat pengelola dalam setiap aktivitas pengelolaan, serta memberikan kepercayaan kepada anggota untuk dapat merefleksikan aksinya pada tindakan kolektif melalui pelaksanaan kegiatan bersama.
\end{abstract}

Kata kunci: Hutan Nagari, partisipasi, pembangunan berkelanjutan, pengelolaan

\section{Pendahuluan}

Konsep pembangunan berkelanjutanmerupakan isu global yang terus menerus didengungkan oleh PBB. Salah satunya adalah dengan terus diperbaharuinya rencana pembangunan berkelanjutan dunia sebagai konsep yang melandasi suatu pengelolaan lingkungan dengan didorong oleh ekspansi kapitalisme global yang berdampak pada menurunnya kualitas pengelolaan lingkungan di berbagai negara. Konsep pembangunan berkelanjutan tersebut tertuang dalam Sustainable Development Goals (SDGs) yang diharapkan dapat menanggulangi berbagai masalah seperti kemiskinan dan kelaparan, memajukan kesehatan dan pendidikan, hingga konservasi lingkungan (United Nations, 2015). Salah satu permasalahan yang disoroti dalam SDGs 
adalah isu pengelolaan hutan beserta fungsi-fungsinya. Kondisi hutan dunia selama 35 tahun terakhir telah mencapai titik kritis hingga mendegradasi fungsifungsi utama hutan, yaitu fungsi konservasi, fungsi produksi dan fungsi lindung. Hal tersebut menjadi penyebab berbagai bencana alam yang terjadi di dunia seperti banjir, tanah longsor, kabut asap, berkurangnya sumber air bersih, kekeringan, hingga perubahan iklim global yang pada akhirnya mengakibatkan kerugian materi hingga korban jiwa. Target SDGs yang berkaitan dengan hutan antara lain adalah mengimplementasikan pengelolaan berkelanjutan untuk semua jenis hutan, memberantas penebangan hutan, serta memulihkan degradasi hutan dengan reboisasi dan peremajaan hutan (United Nations, 2015).

Indonesia merupakan negara dengan tingkat kerusakan hutan paling parah kedua di dunia dan tercatat sebagai negara dengan laju deforestasi paling tinggi yaitu dua juta hektar per tahun (CIFOR, 2015). Salah satu penyebab terbesar adalah buruknya kebijakan serta implementasi pengelolaan hutan. Diluncurkannya Undang-Undang Nomor 41 Tahun 1999 tentang Kehutanan menjadi salah satu jalan keluar kegagalan pengelolaan hutan masa lalu. UndangUndang ini merupakan pergeseran dari paradigma lama pengelolaan hutan berbasis produksi menjadi pengelolaan hutan yang berpihak pada kesejahteraan masyarakat. Tindak lanjut dari UU 41/1999 tersebut adalah dengan disahkannya Peraturan Pemerintah No. 6 Tahun 2007 (PP 6/2007) Peraturan Pemerintah No. 3 Tahun 2008 (PP 3/2008) tentang Tata Hutan dan Penyusunan Rencana Pengelolaan Hutan, Serta Pemanfaatan Hutan. Permasalahan pemberdayaan masyarakat sebagai basis utama dari pengelolaan hutan ini terdapat pada PP 6/2007 yang secara khusus dibahas pada Bagian Kesebelas "Pemberdayaan Masyarakat Setempat" yang terdapat dalam Bab IV Pemanfaatan Hutan. Berdasarkan PP tersebut, pengelolaan hutan diadopsi melalui tiga skema, yaitu Hutan Desa, Hutan Kemasyarakatan, dan kemitraan. Lebih lanjut, kebijakan pengelolaan Hutan Kemasyarakatan disempurnakan dengan disahkannya Peraturan Menteri Kehutanan No. P.52/Menhut-II/2011 danPengelolaan Hutan Desa dengan Peraturan Menteri Kehutanan No. P.53/Menhut-II/2011.

Esensi dari program Pengelolaan Hutan Berbasis Masyarakat (PHBM) adalah partisipasi atau keterlibatan masyarakat dalam pemanfaatan sumberdaya hutan danikut serta dalam pengamanan dan perlindungannya untuk mewujudkan kelestarian hutan dan kesejahteraan masyarakat (Gunawan et al., 2014). Dengan kata lain, sesuai dengan modul pelaksanaan pengelolaan PHBM oleh Kementerian Kehutanan, partisipasi masyarakat merupakan fitur kunci dari keberhasilan program PHBM. Dengan konsep baru tersebut, PHBM terbukti mampu memberikan dampak positif terhadap masyarakat melalui peran serta masyarakat dalam kegiatan pengelolaan mulai dari perencanaan hingga evaluasi. Dampak positif tersebut dapat berupa peningkatan penghasilan masyarakat, meningkatkan kelestarian lingkungan hutan, menurunkan kasus pembalakan liar, dan berkurangnya lahan kosong karena peran aktif masyarakat dalam mengolah lahan dan melakukan reboisasi (Nasikh, 2009; Damayatanti, 2011; Ngabdani et al., 2015)

Meski demikian, masih saja ditemukan implementasi yang belum optimal karena rendahnya pemberdayaan dan partisipasi masyarakat dalam kegiatan pengelolaan. Utama et al., (2010) menemukan bahwa kegiatan pemberdayaan kelompok tani hutan relatif rendah karena kurangnya partisipasi masyarakat dalam kegiatan pemberdayaan diakibatkan seluruh kegiatan sudah ditentukan lebih dulu oleh Perhutani. Selain itu, Suprayitno (2011) juga menemukan bahwa tingkat partisipasi masyarakat dalam pengelolaan hutan masih tergolong rendah dikarenakan rendahnya tingkat keberdayaan dan kurang optimalnya tingkat kemampuan masyarakat sekitar hutan dalam mengelola dan memanfaatkan hasil hutan. Kurangnya keterlibatan masyarakat dalam sebagian kegiatan perencanaan dan pelaksanaan program, serta tidak adanya penyuluhan yang teratur mengakibatkan masyarakat tidak mendapatkan informasi yang cukup, sehingga masyarakat menjadi kurang termotivasi dalam melaksanakan kegiatan program secara keseluruhan. Padahal, menurut Suprayitno (2008) pelibatan masyarakat dalam kegiatan pemberdayaan dalam rangka pelestarian dan pengelolaan hutan merupakan merupakan hal mendasar untuk mengembangkan dan membangun kesadaran kritis masyarakat pengelola hutan.

Implementasi yang kurang optimal ini juga disebabkan oleh kurangnya pengetahuan masyarakat mengenai program PHBM di lapangan, rendahnya peran serta lembaga masyarakat pengelola hutan dan pesanggem (penggarap), dan belum luasnya jaringan kerjasama. Selain itu, proses komunikasi 
partisipatif yang berjalan kurang optimal serta kurangnya partisipasi masyarakat dalam kegiatan PHBM juga turut menjadi penyebab utama kurang berkembangnya program PHBM di lapangan. Padahal, aktivitas-aktivitas komunikasi partisipatif yang terdiri atas dialog, voice, liberating pedagogy dan aksi refleksi merupakan salah satu fitur kunci untuk mendorong keberhasilan PHBM sebagai bagian dari program pembangunan berkelanjutan. (Tufte dan Mefalopulos, 2009; Nugroho, 2011; Nandini, 2013; Sutejo, 2014; Wilujeng, 2015), oleh karena itu diperlukan partisipasi maksimal dari semua pihak pada setiap kegiatan, baik pengurus maupun masyarakat. Partisipasi dapat mendorong semua pelaku yang terlibat (stakeholders) saling berbagi informasi, pengetahuan, serta dapat menyelesaikan permasalahan secara bersama-sama(Susanti, 2013; Muchtar et al., 2014). Berdasarkan hal tersebut, diperlukan penelitian mengenai tingkat partisipasi masyarakat sebagai kunci utama dalam PHBM yang mengusung prinsip keberlanjutan. Sebab, diduga tanpa adanya partisipasi aktif masyarakat anggota pelaksanaan pengelolaan hutan berbasis masyarakat, prinsip keberlanjutan yang terdiri atas aspek ekonomi, ekologi, dan sosial budaya (Harris, 2000; Streurer et al., 2005; WCCD, 2006) yang diusung oleh program ini tidak akan tercapai secara optimal.

Sumatera Barat merupakan salah satu Provinsi yang menerapkan PHBM dalam bentuk Hutan Desa yang dinamakan Hutan Nagari. Nagari merupakan istilah yang menggambarkan masyarakat yang tersusun ke dalam unit kesatuan masyarakat adat di Sumatera Barat. Peran nagari dalam pengelolaan hutan ini salah satunya dikukuhkan dalam Perda No.10 tentang Tanah Ulayat dan Perda No.2 Tahun 2007 tentang Pokokpokok Pemerintahan Nagari.

Pelaksanaan pengelolaan Hutan Nagari dimaksudkan untuk memberikan akses kepada nagari melalui lembaga nagari dalam mengelola sumberdaya hutan secara lestari dengan prinsip partisipatif untuk kegiatan pemberdayaan masyarakat, sehingga partisipasi masyarakat diperlukan untuk mencapai tujuan tersebut. Kurangnya keikutsertaan masyarakat dalam pelaksanaan program pengelolaan hutan menyebabkan implementasinya menjadi kurang optimal (Wilujeng, 2015). Hal ini mengindikasikan bahwa tanpa adanya partisipasi masyarakat dalam pelaksanaan pengelolaan pada setiap aktivitas Hutan Nagari tidak akan berlangsung sebagaimana mestinya, sehingga tujuan akhir pengelolaan Hutan Nagari sebagai bagian dari pembangunan berkelanjutan yaitu pemberdayaan masyarakat khususnya masyarakat sekitar hutan menjadi tidak berjalan.

Penelitian mengenai implementasi PHBM dan tingkat partisipasi serta pemberdayaan bagi masyarakat maupun lembaga pengelola secara umum telah cukup banyak dilakukan seperti oleh Wilujeng (2015), Wiyonoputri (2014), Guniastuti et al., (2014), Gunawan et al., (2014), Anomsari (2013), Nandini (2013) dan Nugroho (2011), akan tetapi penelitian mengenai partisipasi masyarakat dalam pengelolaan Hutan Nagari sebagai salah satu alat pembangunan berkelanjutan masih belum banyak dilakukan. Berdasarkan hal tersebut, secara umum tujuan penelitian ini adalah untuk menganalisis hubungan partisipasi masyarakat dalam mengelola Hutan Nagari secara berkelanjutan oleh masyarakat. Sementara itu, tujuan khusus dari penelitian ini adalah untuk: 1) mendeskripsikan tingkat partisipasi masyarakat dalam pengelolaan Hutan Nagari; dan 2) mengalisa hubungan partisipasi masyarakat dengan pengelolaan Hutan Nagari secara berkelanjutan.

\section{Metode Penelitian}

Penelitian ini dirancang sebagai penelitian survei eksplanatif. Lokasi penelitian dipilih secara purposif yaitu di lembaga pengelolaan Hutan Nagari atau LPHN Sungai Buluh dan LPHN Paru Provinsi Sumatera Barat. LPHN Sungai Buluh dipilih karena merupakan salah satu lokasi pengelolaan Hutan Nagari terbaik di Sumatera Barat, didukung dengan penghargaan tingkat Nasional kategori Hutan Desa bidang Pengendalian Daerah Aliran Sungai dan Hutan Lindung (PDASHL). Sementara itu, Nagari Paru dipilih karena berdasarkan keterangan dari Dinas Kehutanan Provinsi Sumatera Barat, lokasi tersebut merupakan lokasi pengelolaan Hutan Nagari dengan pengelolaan yang masih belum terlalu maksimal. Penelitian ini dilaksanakan pada bulan Maret hingga April 2016.

Populasi dalam penelitian lapangan ini merupakan anggota masyarakat pengelola di LPHN Sungai Buluh dan LPHN Paru. Pengambilan sampel dilakukan secara sensus, yaitu seluruh anggota LPHN Sungai Buluh yang berjumlah 52 orang dan LPHN Paru yang berjumlah 21 orang. Data yang diambil merupakan data kuantitatif dengan menggunakan 
kuisioner dan data kualitatif yang diperoleh melalui wawancara mendalam terhadap beberapa key informan, focus group discussion (FGD) dan observasi langsung di lapangan.

Data kuantitatif dianalisa dengan menggunakan statistik deskriptif dan uji statistik inferensia. Analisa statistik deskriptif menggunakan tabel frekuensi dan persentase, sedangkan analisa statistik inferensia menggunakan uji chi square dan rank Spearman untuk menguji korelasi dan uji beda mann Whitney untuk membandingkan dua daerah dengan bantuan software SPSS 21.0. Selanjutnya, informasi dari data kualitatif dalam penelitian ini digunakan untuk mempertajam dan mendukung analisa kuantitatif.

\section{Hasil dan Pembahasan}

\section{Karakteristik Individu}

Berdasarkan data pada Tabel 1 terlihat bahwa sebesar 61,5\% anggota LPHN Sungai Buluh dan 47,6\% di LPHN Paru berada pada kisaran umur 30-49 tahun (dewasa). Hal ini berarti sebagian besar angota pengelola LPHN di kedua wilayah tergolong produktif sehingga seperti yang diungkapkan oleh Riana et al., (2015) dan Sadono et al., (2014), kemampuan anggota dalam mengelola Hutan Nagari akan lebih baik sebab anggota berusia produktif lebih mampu menerima informasi dan mengadopsi teknologi agar pengelolaan Hutan Nagari berlangsung lebih optimal.

Tingkat pendidikan formal responden di kedua LPHN tergolong sedang (SMA), yaitu 42,3\% di LPHN Sungai Buluh dan 47,6\% di LPHN Paru. Sementara itu, sebagian besar anggota LPHN di kedua wilayah terdiri atas laki-laki, yaitu 94,2\% di LPHN Sungai Buluh dan 52,4\% di LPHN Paru. Seperti halnya yang ditengarai Wibowo et al., (2012), pengaruh budaya lokal mengenai perbedaan pria dan wanita dalam mengelola Hutan Nagari di kedua LPHN masih kental. Hal ini juga diungkapkan oleh ketua LPHN Paru:

"Masyarakat masih lebih percaya laki-laki
dalam mengerjakan pengelolaan Hutan
Nagari ini dibanding perempuan karena
laki-laki dianggap bisa menangani berbagai
masalah." (Pak I, 48 tahun).

Sebesar 50\% anggota LPHN Sungai Buluh dan $66,7 \%$ LPHN Paru memiliki pekerjaan sebagai petani/ buruh. Berdasarkan observasi di lapangan, apapun jenis pekerjaan tetap yang dimiliki oleh pengurus atau anggota LPHN tidak berhubungan dengan kedudukan mereka dalam lembaga, sehingga hal ini tidak sejalan dengan pendapat Hendri et al., (2014) bahwa jenis pekerjaan dianggap berhubungan dengan efektivitas musyawarah dalam perencanaan pembangunan. Sehubungan dengan hal tersebut, proporsi pendapatan anggota yang berasal dari hutan di kedua LPHN berada pada kategori sedang $(20 \%-49 \%)$.

\section{Komunikasi Partisipatif dalam Pengelolaan Hutan Nagari}

Proses perencanaan dan monitoring evaluasi di LPHN Sungai Buluh awalnya dilakukan antar pengurus, fasilitator dari dinas kehutanan dan KKI Warsi, dan tokoh nagari. Rancangan awal rencana kerja yang telah selesai dirancang dibawa ke forum rapat bulanan, yang mana rutin dilaksanakan pada tanggal 20 setiap bulan, untuk dipresentasikan kepada anggota lain.

Demikian juga halnya dengan rancangan awal monitoring dan evaluasi. Kegiatan diskusi tersebut berlangsung secara dialogis di mana masyarakat anggota secara aktif menyampaikan pendapatnya mengenai rancangan tersebut. Masyarakat anggota dapat menyampaikan aspirasi (voice) mereka secara lebih terbuka dalam kegiatan diskusi bulanan ini. Hal ini sejalan dengan temuan Muslikhah (2015) bahwa penyampaian voice/aspirasi ini membuat dialog berlangsung lebih aktif antar seluruh pihak yang terlibat dalam kegiatan pengelolaan Hutan Nagari, sebab semua pihak baik anggota, pengurus, maupun pihak fasilitator dapat menyampaikan pendapat mereka.

Sebaliknya, diskusi aktivitas perencanaan dan monitoring evaluasi di LPHN Paru berlangsung hanya sesama pengurus dan fasilitator dari dinas kehutanan dan pada umumnya tidak terlalu melibatkan anggota. Meskipun ada anggota yang terlibat, hanya terdiri atas anggota-anggota yang dinilai aktif dan berpengaruh di antara anggota lainnnya karena memiliki posisi sosial di masyarakat seperti Ketua Pemuda. Pada tahap ini, kegiatan dikusi dan penyampaian aspirasi yang dilakukan atas keinginan sendiri tergolong tinggi, hanya saja hal tersebut terjadi di tingkat pengurus, sementara anggota kurang dilibatkan. Hal ini menyebabkan aspek-aspek komunikasi partisipatif yang dialogis pada penyampaian aspirasi atas keinginan dan kesadaran 
Tabel 1. Jumlah dan Persentase Karakteristik Individu Masyarakat Pengelola Hutan Nagari Sungai Buluh dan Paru Sumatera Barat, 2016

\begin{tabular}{|c|c|c|c|c|c|c|}
\hline \multirow{2}{*}{ No. } & \multirow{2}{*}{ Karakteristik Individu } & \multicolumn{2}{|c|}{ LPHN Sungai Buluh } & \multicolumn{2}{|c|}{ LPHN Paru } & \multirow{2}{*}{ Uji Beda } \\
\hline & & Jumlah (orang) & Frekuensi (\%) & Jumlah (orang) & Frekuensi (\%) & \\
\hline \multirow[t]{5}{*}{1.} & Umur & & & & & \\
\hline & Muda (17-29 tahun) & 11 & 21,2 & 9 & 42,9 & $0,039^{*}$ \\
\hline & Dewasa (30-49 tahun) & 32 & 61,5 & 10 & 47,6 & \\
\hline & Tua ( $\geq 50$ tahun) & 9 & 17,3 & 2 & 9,5 & \\
\hline & Jumlah & 52 & 100,0 & 21 & 100,0 & \\
\hline \multirow[t]{5}{*}{2.} & Tingkat Pendidikan formal & & & & & \\
\hline & Rendah (SDdanSMP) & 19 & 36,5 & 7 & 33,3 & 0,932 \\
\hline & Sedang (SMA) & 22 & 42,3 & 10 & 47,6 & \\
\hline & Tinggi (Perguruan Tinggi) & 11 & 21,2 & 4 & 19,0 & \\
\hline & Jumlah & 52 & 100,0 & 21 & 100,0 & \\
\hline \multirow[t]{4}{*}{3.} & Jenis Kelamin & & & & & \\
\hline & Laki-laki & 49 & 94,2 & 11 & 52,4 & $0,000^{* *}$ \\
\hline & Perempuan & 3 & 5,8 & 10 & 47,6 & \\
\hline & Jumlah & 52 & 100,0 & 21 & 100,0 & \\
\hline \multirow[t]{5}{*}{4.} & Jenis Pekerjaan & & & & & \\
\hline & Petani/buruh & 26 & 50,0 & 14 & 66,7 & 0,579 \\
\hline & Wiraswasta & 18 & 34,6 & 1 & 4,8 & \\
\hline & Pegawai negeri/swasta & 8 & 15,4 & 6 & 28,6 & \\
\hline & Jumlah & 52 & 100,0 & 21 & 100,0 & \\
\hline \multirow[t]{5}{*}{5.} & $\begin{array}{l}\text { Proporsi Pendapatan dari } \\
\text { Hutan }\end{array}$ & & & & & \\
\hline & Rendah $(<20 \%)$ & 21 & 40,4 & 6 & 28,6 & 0,125 \\
\hline & Sedang $(20 \%-49 \%)$ & 29 & 55,8 & 11 & 52,4 & \\
\hline & Tinggi $(\geq 50 \%)$ & 2 & 3,8 & 4 & 19,0 & \\
\hline & Jumlah & 52 & 100,0 & 21 & 100,0 & \\
\hline
\end{tabular}

${ }^{*}$.Correlation is significant at the 0,05 level (2-tailed) $\quad{ }^{* *}$.Correlation is significant at the 0,01 level (2-tailed)

sendiri di LPHN Paru menjadi kurang sehingga banyak informasi yang tidak diterima dan dimengerti oleh anggota. Hal tersebut seperti yang ditengarai oleh Zainal et al., (2014) bahwa tanpa adanya komunikasi partisipatif dalam suatu program, maka informasi dan pesan yang disampaikan banyak yang tidak dimengerti atau dipahami oleh masyarakat.

Pada kegiatan penetapan batas wilayah, masyarakat anggota baik di LPHN Sungai Buluh maupun LPHNParu kurang dilibatkan. Pada umumnya, pihak-pihak yang terlibat dalam penetapan batas wilayah adalah pihak pengurus inti dan fasilitator, baik dari dinas kehutanan, maupun dari LSM terkait, seperti
KKI Warsi yang mendampingi LPHN Sungai Buluh sehingga komunikasi partisipatif hanya berlangsung di antara pihak-pihak tersebut sementara anggota menjadi kurang dilibatkan. Namun, hal tersebut tidak menjadi penghambat dalam kegiatan pengelolaan karena sudah adanya persetujuan bersama bahwa kegiatan penetapan batas wilayah hanya dilakukan oleh pihakpihak tertentu saja. Sejalan dengan Sadono et al., (2014) bahwa sudah ada anggapan dari anggota bahwa keterlibatan mereka tidak terlalu diperlukan sehingga cukup dilakukan oleh pengurus inti saja.

Berdasarkan Tabel 2, tahap pelaksanaan kegiatan merupakan salah satu aktivitas yang paling 
Tabel 2. Jumlah dan Persentase Komunikasi Partisipatif Masyarakat LPHN Sungai Buluh dan LPHN Paru Sumatera Barat, 2016

\begin{tabular}{|c|c|c|c|c|c|}
\hline \multirow{2}{*}{$\begin{array}{c}\text { Proses Komunikasi } \\
\text { Partisipatif (X2) } \\
\end{array}$} & \multicolumn{2}{|c|}{ LPHN Sungai Buluh } & \multicolumn{2}{|c|}{ LPHN Paru } & \multirow{2}{*}{$\begin{array}{c}\text { Uji } \\
\text { Beda }\end{array}$} \\
\hline & Jumlah (orang) & Frekuensi (\%) & Jumlah (orang) & Frekuensi (\%) & \\
\hline \multicolumn{6}{|l|}{ Dialog (X2.1) } \\
\hline Tinggi & 21 & 40,4 & 7 & 33,3 & $0,015^{*}$ \\
\hline Sedang & 31 & 59,6 & 13 & 61,9 & \\
\hline Rendah & 0 & 0 & 1 & 4,8 & \\
\hline \multicolumn{6}{|l|}{ Voice (X2.2) } \\
\hline Tinggi & 49 & 94,2 & 6 & 28,6 & $0,000^{* *}$ \\
\hline Sedang & 3 & 5,8 & 14 & 66,7 & \\
\hline Rendah & 0 & 0 & 1 & 4,8 & \\
\hline \multicolumn{6}{|c|}{ Liberating pedagogy (X2.3) } \\
\hline Tinggi & 45 & 86,5 & 14 & 66,7 & $0,005^{* *}$ \\
\hline Sedang & 7 & 13,5 & 6 & 28,6 & \\
\hline Rendah & 0 & 0 & 1 & 4,8 & \\
\hline \multicolumn{6}{|l|}{ Aksi-Refleksi (X2.4) } \\
\hline Tinggi & 34 & 65,4 & 8 & 38,1 & 0,089 \\
\hline Sedang & 18 & 34,6 & 10 & 47,6 & \\
\hline Rendah & 0 & 0 & 3 & 14,3 & \\
\hline \multicolumn{6}{|c|}{ Komunikasi partisipatif keseluruhan (X2) } \\
\hline Tinggi & 49 & 94,2 & 14 & 66,7 & $0,000^{* *}$ \\
\hline Sedang & 3 & 5,8 & 6 & 28,6 & \\
\hline Rendah & 0 & 0 & 1 & 4,8 & \\
\hline Jumlah & 52 & 100,0 & 21 & 100,0 & \\
\hline
\end{tabular}

banyak mengedepankan komunikasi partisipatif yang melibatkan seluruh anggota masyarakat pengelola baik di LPHN Sungai Buluh maupun di LPHN Paru. Salah satunya adalah pada kegiatan rapat bulanan. Di LPHN Sungai Buluh, tidak ada perbedaan antara seluruh pihak yang terlibat dalam kegiatan rapat, baik pengurus, anggota, tua/muda atau berpendidikan tinggi/tidak dalam kegiatan pengelolaan Hutan Nagari. Kegiatan ini menjadi ajang refleksi-aksi yang tidak hanya membahas kegiatan pengelolaan yang telah dilakukan, akan tetapi juga membahas permasalahan dan konflik internal yang mungkin munculdan dapat menghambat keberlangsungan pengelolaan Hutan Nagari ke depannya. Hal ini sejalan dengan hasil temuan Satriani et al., (2011) di mana komunikasi partisipatif dalam suatu lembaga selain menjadi ajang berbagi informasi dan pengetahuan, juga menjadi wadah untuk penyelesaian permasalahan secara bersama-sama sehingga diharapkan akan terjalin keakbaran yang lebih erat antar sesama anggota.

Kegiatan rapat bulanan di LPHN Paru dilaksanakan bersama pengurus dan anggota untuk membahas kegiatan pengelolaan Hutan Nagari. Diskusi dan penyampaian aspirasi terutama tercermin dari interaksi antara sesama anggota dan antara sesama pengurus inti serta antar pengurus dan fasilitator serta pihak-pihak dari dinas kehutanan. Akan tetapi, diskusi dan penyampaian aspirasi antara anggota dengan pihak fasilitator, terutama pihak dinas berlangsung kurang partisipatif.

Hubungan antara pihak dinas dan masyarakat anggota belum terlalu erat diakibatkan berbagai hal, terutama karena rendahnya intensitas kunjungan pihak dinas sebagai fasilitator dan pendukung utama dari pengembangan Hutan Nagari. Hal ini terjadi karena minimnya media komunikasi yang memungkinkan untuk menghubungi Nagari Paru sehingga pihak dinas cenderung jarang mengunjungi LPHN Paru. Kunjungan lebih sering dilakukan ketika ada kegiatan khusus atau kegiatan bersama di LPHN tersebut. Hal ini merupakan faktor utama penyebab komunikasi masyarakat pengelola dengan pemerintah berlangsung 
kurang aktif sehingga LPHN Paru masih belum berkembang hingga saat ini.

\section{Faktor Dukungan Pengelolaan Hutan Nagari}

Berdasarkan Tabel 3, dukungan dari tokoh nagari di kedua wilayah merupakan bentuk dukugan paling tinggi yang diterima oleh LPHN dibandingkan dukungan lainnya. Hal ini mengindikasikan bahwa dukungan dari tokoh nagari merupakan dukungan utama dalam pengelolaan Hutan Nagari di kedua wilayah. Hal ini diperkuat dengan berbagai bentuk dukungan yang diberikan oleh nagari.

Di Nagari Sungai Buluh dukungan tersebut antara lain berupa: dukungan pada proposal pembentukan Hutan Nagari kepada pemerintah, dibentuknya Peraturan Nagari Sungai Buluh Nomor 08 Tahun 2012 tentang Lembaga Pengelolaan Hutan Nagari Sungai Buluh, Surat Pernyataan Komitmen Masyarakat Sungai Buluh mengenai Hutan Nagari yang diwakili oleh Wali Nagari, ketua Badan Musyawarah Nagari (BAMUS) dan ketua Kerapatan Adat Nagari (KAN), dan Surat Keputusan Wali Nagari Sungai Buluh Nomor 02/SK/WN/I-2014 Tentang Pembentukan Susunan Pengurus LPHN Sungai Buluh.
Dukungan tokoh nagari terhadap LPHN Paru juga beragam, terutama karena sebelum dibentuknya Hutan Nagari wilayah hutan di Nagari Paru merupakan wilayah hutan lindung atau "rimbo larangan" yang didasarkan pada Peraturan Nagari Paru No. 1 tahun 2002. Salah satu dukungan utama dari tokoh nagari yang membantu berdirinya Hutan NagariParu saat ini adalah terbitnya Peraturan Wali Nagari Paru Nomor 1 tahun 2015 tentang Lembaga Pengelolaan Hutan Nagari.

Hal ini berarti kelancaran dan perkembangan LPHN Sungai Buluh dan LPHN Paru bukan tergantung dari pihak-pihak dari luar seperti pemerintah atau LSM, tetapi berasal dari dalam lingkup komunitas mereka sendiri sehingga tujuan dari pengelolaan hutan berbasis masyarakat dapat dicapai secara optimal, yaitu dengan mengandalkan seluruh sumberdaya yang berasal dari nagari secara maksimal untuk kepentingan bersama. Hal ini seperti yang dinyatakan oleh Lynch dan Harwell (2006) bahwa kekuatan lokal untuk mengikuti aturan dan juga kedekatan dengan sumberdaya alam, merupakan landasan untuk mendorong proses pengakuan kapasitas kelembagaan pengelolaan sumberdaya alam berbasis masyarakat lokal.

Tabel 3. Jumlah dan Persentase Faktor Dukungan LPHN Sungai Buluh dan LPHN Paru Sumatera Barat, 2016

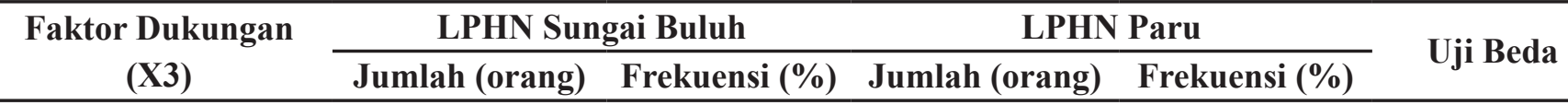

\begin{tabular}{|c|c|c|c|c|c|}
\hline \multicolumn{6}{|c|}{ Tingkat dukungan pemerintah lokal (X3.1) } \\
\hline Tinggi & 34 & 65,4 & 11 & 52,4 & \multirow[t]{3}{*}{$0,000^{* *}$} \\
\hline Sedang & 18 & 34,6 & 9 & 42,9 & \\
\hline Rendah & 0 & 0 & 1 & 4,8 & \\
\hline \multicolumn{6}{|c|}{ Tingkat dukungan pemerintah nagari (X3.2) } \\
\hline Tinggi & 42 & 80,8 & 12 & 57,1 & \multirow[t]{3}{*}{$0,030^{*}$} \\
\hline Sedang & 10 & 19,2 & 9 & 42,9 & \\
\hline Rendah & 0 & 0 & 0 & 0 & \\
\hline \multicolumn{6}{|c|}{ Tingkat dukungan berupa sumberdaya (X3.3) } \\
\hline Tinggi & 26 & 50,0 & 7 & 33,3 & \multirow[t]{3}{*}{$0,004^{* *}$} \\
\hline Sedang & 26 & 50,0 & 8 & 38,1 & \\
\hline Rendah & 0 & 0 & 6 & 28,6 & \\
\hline \multicolumn{6}{|c|}{ Faktor dukungan keseluruhan (X3) } \\
\hline Tinggi & 45 & 86,5 & 11 & 52,4 & \multirow[t]{4}{*}{$0,000^{* *}$} \\
\hline Sedang & 7 & 13,5 & 9 & 42,9 & \\
\hline Rendah & 0 & 0 & 1 & 4,8 & \\
\hline Jumlah & 52 & 100,0 & 21 & 100,0 & \\
\hline
\end{tabular}


Dukungan dari pemerintah yang diterima oleh LPHN Sungai Buluh dan LPHN Paru pada dasarnya tidak berbeda, terutama dalam hal peraturan dan advokasi atau jaminan keamanan dan kelegalan Hutan Nagari. Di Nagari Sungai Buluh, peraturan pendukung tersebut antara lain berupa adanya Keputusan Menteri Kehutanan Republik Indonesia Nomor: SK.856/ Menhut-II/2013 Tentang Penetapan Areal Kerja Hutan Nagari Sungai Buluh Seluas \pm 1.336 Hektar Pada Kawasan Hutan Lindung di Kecamatan Batang Anai Kabupaten Padang Pariaman; dan Keputusan Gubernur Sumatera Barat Nomor: 522.4-789-2014 Tentang Pemberian Hak Pengelolaan Hutan Nagari Pada Kawasan Hutan Lindung Seluas \pm 780 Hektar kepada LPHN Sungai Buluh. Sementara itu, peraturan pendukung di Nagari Paru berupa Surat Keputusan Menteri Kehutanan Republik Indonesia Nomor: SK.507/Menhut-II/2014 Tetang Penetapan Areal Kerja Hutan Nagari Paru Seluas \pm 4.500 Hektar pada Kawasan Hutan Lindung di Kecamatan Sijunjung Kabupaten Sijunjung.

Perbedaan dukungan yang diberikan serta yang diterima antara LPHN Sungai Buluh dan LPHN Paru dari pemerintah terlihat dari intensitas keikutsertaan anggota masyarakat pengelola dalam pelatihan atau pertemuan yang diadakan oleh pemerintah. Selain itu, intensitas kunjungan dari dinas terkait ke LPHN Sungai Buluh dan LPHN Paru juga berbeda. Pihak dinas beserta fasilitatornya lebih sering mengunjungi LPHN Sungai Buluh dibandingkan LPHN Paru. Dalam satu bulan misalnya, diketahui paling sedikit pihak dinas dari provinsi berkunjung dua hingga tiga kali ke LPHN Sungai Buluh, sementara pihak fasilitator dari kabupaten dapat berkunjung lebih sering daripada itu.

Kunjungan pihak dinas ke LPHN Paru cenderung jarang dilakukan. Dalam satu bulan terdapat satu kali kunjungan atau lebih dari satu kali ketika ada acara atau kegiatan bersama, akan tetapi, kunjungan tersebut jarang dilakukan jika tidak ada acara khusus, sehingga bisa saja dalam satu bulan pihak dinas terutama dinas provinsi tidak mengunjungi LPHN Paru. Berdasarkan observasi di lapangan, hal ini juga disebabkan oleh perbedaan akses komunikasi dan transportasi antara Nagari Sungai Buluh dan Nagari Paru. Lemahnya akses komunikasi dan transportasi ke Nagari Paru menyebabkan intensitas kunjungan dari dinas terkait rendah. Demikian juga dengan dukungan yang diiberikan menjadi tidak optimal. Berbeda dengan Nagari Sungai Buluh yang memiliki akses komunikasi yang sangat lancar dan wilayah dengan fasilitas transportasi yang lebih mudah dijangkau.

Dukungan berupa sumberdaya di LPHN Sungai Buluh lebih baik dibanding LPHN Paru. Hal ini tidak terlepas dari peran serta pemerintah dan KKI Warsi dalam memfasilitasi LPHN Sungai Buluh secara intensif sehingga sumberdaya yang diperlukan dapat disalurkan dengan lebih optimal. Bentukbentuk sumberdaya yang disalurkan ke LPHN Sungai Buluh antara lain adalah adanya tenaga pendamping atau fasilitator baik dari pemerintah maupun KKI Warsi, diberikannya bantuan berupa satu unit gedung pertemuan dan akses jalan setapak menuju lokasi Hutan Nagari oleh Wali Nagari, bantuan berupa 4 (empat) buah kubung jamur tiram oleh PT Angkasa Pura (Pertamina), dan bantuan berupa bibit tanaman oleh pemerintah melalui program Kebun Bibit Rakyat (KBR).

Berbeda halnya dengan Nagari Paru yang dari awal memiliki keterbatasan akses informasi dan transportasi, sehingga tingkat dukungan sumberdaya cenderung lebih sedikit. Dukungan berupa fasilitator tidak dapat dimanfaatkan secara optimal, padahal menurut Santoso (2011) pendampingan dari fasilitator memegang peranan penting bagi pengembangan Hutan Desa. Tidak hanya itu, bantuan berupa rumah kompos yang keberadaannya menjadi kurang terjaga dan tidak lagi berfungsi maksimal sebagaimana mestinya.

\section{Tingkat Partisipasi dalam Pengelolaan Hutan Nagari}

Partisipasi dalam kegiatan perencanaan mencakup keikutsertaan seluruh anggota masyarakat pengelola Hutan Nagari dalam merencanakan usaha dan kegiatan Hutan Nagari. Partisipasi seluruh anggota LPHN Sungai Buluh dalam perencanaan terjadi pada saat rancangan awal perencanaan sudah diangkat ke dalam rapat bulanan bersama yang diadakan setiap tanggal 20. Akan tetapi, penyusunan perencanaan awal yang terdiri atas RKHPHN (rencana jangka panjang 35 tahun), RKHN (rencana jangka menengah 10 tahun), dan RTHN (rencana jangka pendek 1 tahun), hanya dilakukan oleh pengurus inti, Wali Nagari, fasilitator dari KKI Warsi dan pemerintah. Oleh karena itu, partisipasi anggota LPHN Sungai Buluh dalam aspek perencanaan berada pada kategori sedang. Sebaliknya, partisipasi anggota LPHN Paru pada aspek perencanaan tergolong rendah karena kegiatan 
Tabel 4. Jumlah dan Persentase Tingkat Partisipasi Masyarakat dalam Pengelolaan Hutan Nagari di LPHN Sungai Buluh dan Paru Sumatera Barat, 2016

\begin{tabular}{|c|c|c|c|c|c|}
\hline \multirow{2}{*}{$\begin{array}{l}\text { Tingkat Partisipasi } \\
\text { dalam Pengelolaan } \\
\text { Hutan Nagari (Y1) }\end{array}$} & \multicolumn{2}{|c|}{ LPHN Sungai Buluh } & \multicolumn{2}{|c|}{ LPHN Paru } & \multirow{2}{*}{ Uji Beda } \\
\hline & Jumlah (orang) & Frekuensi (\%) & Jumlah (orang) & Frekuensi (\%) & \\
\hline \multicolumn{6}{|l|}{ Perencanaan (Y1.1) } \\
\hline Tinggi & 6 & 11,5 & 5 & 23,8 & $0,014^{*}$ \\
\hline Sedang & 36 & 69,2 & 3 & 14,3 & \\
\hline Rendah & 10 & 19,2 & 13 & 61,9 & \\
\hline \multicolumn{6}{|c|}{ Penetapan batas areal kerja (Y1.2) } \\
\hline Tinggi & 7 & 13,5 & 4 & 19,0 & $0,017^{*}$ \\
\hline Sedang & 8 & 15,4 & 4 & 19,0 & \\
\hline Rendah & 37 & 71,2 & 13 & 61,9 & \\
\hline \multicolumn{6}{|c|}{ Pelaksanaan kegiatan (Y1.3) } \\
\hline Tinggi & 23 & 44,2 & 5 & 23,8 & $0,002^{* *}$ \\
\hline Sedang & 29 & 55,8 & 7 & 33,3 & \\
\hline Rendah & 0 & 0 & 9 & 42,9 & \\
\hline \multicolumn{6}{|c|}{ Monitoring dan evaluasi (Y1.4) } \\
\hline Tinggi & 0 & 0 & 2 & 9,5 & 0,121 \\
\hline Sedang & 26 & 50,0 & 7 & 33,3 & \\
\hline Rendah & 26 & 50,0 & 12 & 57,1 & \\
\hline \multicolumn{6}{|c|}{ Tingkat partisipasi dalam hutan nagari secara keseluruhan (Y1) } \\
\hline Tinggi & 7 & 13,5 & 4 & 19,0 & $0,021^{*}$ \\
\hline Sedang & 45 & 86,5 & 6 & 28,6 & \\
\hline Rendah & 0 & 0 & 11 & 52,4 & \\
\hline Jumlah & 52 & 100,0 & 21 & 100,0 & \\
\hline
\end{tabular}

perencanaan juga hanya dilakukan oleh pengurus inti dan pihak pemerintah, dengan sedikit sekali melibatkan anggota di dalam pengesahan akhirnya. Bahkan terdapat beberapa anggota yang tidak tahu jenis-jenis rencana kerja LPHN Paru, yang juga terdiri atas RKHPHN, RKHN, dan RTHN.

Partisipasi anggota dalam penetapan batas areal kerja pada LPHN Sungai Buluh dan LPHN Paru sama-sama berada pada kategori rendah. Rendahnya partisipasi penetapan batas areal kerja pada kedua wilayah disebabkan karena kegiatan tersebut tidak dilakukan bersama seluruh anggota LPHN, tetapi hanya dilaksanakan oleh beberapa pengurus inti. Partisipasi anggota dalam penetapan batas areal kerja di LPHN Sungai Buluh lebih rendah dibandingkan LPHN Paru. Hal ini terjadi karena penetapan batas areal kerja di LPHN Sungai Buluh masih sebatas rencana awal dan belum sampai pada tahap realisasi. Belum dilaksanakannya penetapan batas areal kerja di Sungai Buluh disebabkan oleh berbagai kendala seperti keterbatasan dana, sulitnya mencari titik-titik penetapan batas wilayah yang tepat, kekurangan peralatan, dan kurangnya sumberdaya yang mumpuni. Hingga saat ini, rencana penetapan batas wilayah di LPHN Sungai Buluh hanya mengikutsertakan ketua LPHN, fasilitator dari KKI Warsi dan fasilitator dari Dinas Kehutanan Provinsi Sumatera Barat. Sementara itu, kegiatan penetapan batas areal di Nagari Paru sudah dijalankan, sehingga beberapa orang anggota diikutsertakan, terutama yang memiliki areal ladang di daerah batas wilayah. Oleh karena itu, partisipasi di LPHN Paru dalam penetapan batas areal kerja lebih tinggi dibandingkan LPHN Sungai Buluh.

Tingkat partisipasi masyarakat pengelola dalam pelaksanaan kegiatan di LPHN Sungai Buluh lebih tinggi dibanding LPHN Paru. Hal ini karena masyarakat di Nagari Sungai Buluh selalu berusaha untuk ikut serta dan berpartisipasi aktif dalam setiap kegiatan yang diadakan. Partisipasi anggota di LPHN Sungai Buluh salah satunya terlihat pada keikutsertaan 
masyarakat anggota berdiskusi dan menyampaikan aspirasi mereka dalam kegiatan rapat bersama setiap bulan. Dalam kegiatan rapat dengan konsep musyawarah bersama ini, seluruh masyarakat anggota pengelola LPHN membicarakan hal-hal terkait pengelolaan, termasuk solusi atas tindakan penebangan hutan secara liar yang pada awal berdiri Hutan Nagari di Sungai Buluh banyak dilakukan.

Aktivitas dengan bentuk diskusi dan berbagi pendapat ini diikuti oleh semua pihak yang terlibat, yaitu anggotamasyaraat pengelola, pengurus, KKI Warsi dan fasilitator dari dinas kehutanan. Kegiatan musyawarah terus dilakukan hingga muncul kesepahaman bersama (mutual understanding), sebab seperti yang disampaikan oleh Satriani et al., (2011) dan Kusumadinata et al., (2012) diskusi dialogis mampu meningkatkan keterlibatan masyarakat dalam mensukseskan suatu program, termasuk dalam pengelolaan Hutan Nagari. Kesepahaman bersama ini kemudian menjadi konsensus dari permasalahan yang sedang dihadapi melalui kesepakatan bersama (mutual agreement) terhadap solusi akhir berupa pengalihan lapangan pekerjaan anggota masyarakat yang mata pencarian utamanya berasal dari hasil hutan kayu. Terakhir, tindak lanjut dari kesepakatan bersama adalah tindakan kolektif (collective action) untuk berhenti melakukan penebangan ilegal, kecuali ketika ada izin dan alasan kuat untuk aktivitas tersebut, dan beralih pada pekerjaan yang telah diusulkan dan diterima, seperti menjadi tour guide dan sebagainya (Flor, 2004; Gunawan et al., 2014; Purwatiningsih dan Dahlan, 2015). Hal ini seperti yang juga disampaikan oleh Ketua LPHN Sungai Buluh sebagai berikut:

"Ketika awalnya tidak setuju dengan larangan menebang hutan karena hilangnya mata pencaharian mereka, kami bersamasama mencarikan solusinya. Saya bilang "kalau soal itu kan bisa disampaikan,. Kan usaha yang lain masih bisa, misalnya seperti ke sawah, atau ladang. Segala macamnya kan masih bisa dibikin usaha. Memang kini kita bisa dapat uang senang dan gampang, habis mendapatkan kayu, kita dapat uang. Tapi 50 tahun kemudian, sudahlah badan kita sakitsakit, bencana nan nanti muncul". Setelah diberikan pengertian seperti itu, akhirnya mereka sadar sendiri. Karena itulah sampai saat ini kami sebagai pengurus tidak ada konflik yang serius. Aman tanpa ada masalah berarti”.

Sebaliknya, kurangnya keikutsertaan masyarakat anggota pengelola terutama pada level bawah (grass root)dalamberdiskusidanmenyampaikan aspirasi di LPHN Paru mengakibatkan lebih rendahnya tingkat partisipasi mereka dalam aktivitas pelaksanaan kegiatan seperti ditengarai oleh Guniastuti et al., (2014) dan Wilujeng (2015). LPHN Paru jarang mengadakan kegiatan-kegiatan bersama sehingga tingkat partisipasi anggotanya pun menjadi lebih rendah. Meskipun ada, kegiatan tersebut utamanya diurus oleh pengurus inti seperti ketua LPHN Paru yang lebih dipercaya dan dekat dengan pihak luar seperti pemerintah.

Partisipasi anggota LPHN dalam kegiatan monitoring dan evaluasi di Sungai Buluh berada pada kategori sedang, sementara partisipasi pada LPHN Paru berada pada kategori rendah. Kegiatan monev di LPHN Sungai Buluh dilaksanakan oleh pengurus inti, Wali Nagari, dan fasilitator dari KKI Warsi. Seluruh draft perencanaan dan monitoring evaluasi yang telah selesai dikerjakan dibawa ke forum rapat bulanan. Sebab, meskipun perencanaan dan pembentukan draft awal dikerjakan oleh pengurus inti dibantu oleh fasilitator, keputusan akhir tetap berada pada seluruh anggota pengelola Hutan Nagari. Pada tahap inilah partisipasi seluruh anggota berlangsung cukup dinamis. Rendahnya partisipasi anggota dalam kegiatan monitoring dan evaluasi LPHN Paru disebabkan oleh beberapa hal, terutama jarangnya LPHN tersebut mengadakan kegiatan bersama. Kegiatan monitoring dan evaluasi pun hanya dilakukan bersama pengurus inti, seperti ketua, wakil ketua, bendahara, sekretaris bersama Wali Nagari.

Tingkat partisipasi anggota masyarakat pengelola pada Hutan Nagari Sungai Buluh lebih tinggi dibanding LPHN Paru, terutama dalam aktivitas perencanaan dan pelaksanaan kegiatan. Tergolong rendahnya tingkat partisipasi anggota masyarakat pada aktivitas pengelolaan Hutan Nagari, terutama di LPHN Paru, mengindikasikan bahwa umumnya anggota kurang dilibatkan dalam aktivitas manajamen kelembagaan, yaitu aspek perencanaan, penetapan batas wilayah, pelaksanaan kegiatan dan monitoring evaluasi. Hal ini relevan dengan Sadono et al., (2014) dan Winata dan Yuliana (2012) bahwa dalam kegiatan pengelolaan seperti perencanaan dan monitoring evaluasi, anggota kurang diikutsertakan oleh pengurus. 
Dalam hubungannya dengan pengelolaan Hutan Nagari, rendahnya partisipasi anggota masyarakat pengelola dalam aktivitas pengelolaan sejalan dengan penelitian Salampessy et al., (2010) yang menyatakan bahwa partisipasi anggota masyarakat pengelola terutama dalam kegiatan perencanaan, pelaksanaan kegiatan dan monitoring evaluasi masih tergolong rendah. Guniastuti et al., (2014) menyebutkan bahwa rendahnya partisipasi anggota masyarakat dalam kegiatan monitoring dan evaluasi disebabkan oleh belum adanya kesesuaian antara perecanaan dan pelaksanaan. Sejalan dengan hal tersebut, rendahnya tingkat partisipasi dalam kegiatan monitoring dan evaluasi di LPHN Sungai Buluh dan LPHN Paru diantaranya juga disebabkan oleh masih kurang optimalnya realisasi rencana kegiatan yang telah disusun, terutama di LPHN Paru.

\section{Tingkat Pengelolaan Hutan Nagari Secara Berkelanjutan}

Tingkat pengelolaan Hutan Nagari secara berkelanjutan ditinjau berdasarkan tiga pilar utama pembangunan berkelanjutan, yaitu aspek ekonomi, ekologi, dan sosial budaya (Harris, 2000; Streurer et al., 2005). Aspek ekologi berada pada kategori tinggi di kedua wilayah penelitian. Berdasarkan hasil observasi lapangan dan keterangan dari Ketua LPHN Sungai Buluh dan Ketua LPHN Paru, salah satu dampak paling besar yang dapat dilihat adalah terjadinya penurunan kegiatan pembalakan liar di wilayah Hutan Nagari. Hal ini sejalan dengan Purwatiningsih dan Dahlan (2015), bahwa keterlibatan seluruh stakeholders dalam kegiatan diskusi bersama mengenai pengelolaan dan perlindungan hutan secara partisipatif melahirkan kesepahaman bersama dalam implementasi regulasi dan hukum dapat menanggulangi pelanggaranpelanggaram dalam pemanfaatan hasil hutan, penurunan aktivitas illegal logging di Hutan Nagari Sungai Buluh danHutan Nagari Paru tidak terlepas dari partisipasi aktif pada musyawarah bersama seluruh anggota masyarakat yang sering terlibat melakukan kegiatan illegal logging di kedua wilayah tersebut.

Berdasarkan Tabel 5, aspek sosial dan budaya pada kedua wilayah juga tergolong tinggi. Dampak sosial terbesar dengan adanya Hutan Nagari di Sungai Buluh adalah dengan beralihnya kebiasaan buruk para pemuda desa yang suka mabuk dan berjudi di

Tabel 5. Jumlah dan Pesentase Tingkat Pengelolaan Hutan Nagari Secara Berkelanjutan di LPHN Sungai Buluh dan LPHN Paru Sumatera Barat, 2016

\begin{tabular}{|c|c|c|c|c|c|}
\hline \multirow{2}{*}{$\begin{array}{c}\text { Tingkat Pengelolaan Hutan Nagari } \\
\text { Secara Berkelanjutan (Y2) }\end{array}$} & \multicolumn{2}{|c|}{ LPHN Sungai Buluh } & \multicolumn{2}{|c|}{ LPHN Paru } & \multirow{2}{*}{ Uji Beda } \\
\hline & Jumlah (orang) & Frekuensi (\%) & Jumlah (orang) & Frekuensi (\%) & \\
\hline \multicolumn{6}{|l|}{ Ekonomi (Y2.1) } \\
\hline Tinggi & 5 & 9,6 & 3 & 14,3 & $0,012^{*}$ \\
\hline Sedang & 47 & 90,4 & 11 & 52,4 & \\
\hline Rendah & 0 & 0 & 7 & 33,3 & \\
\hline \multicolumn{6}{|l|}{ Ekologi (Y2.2) } \\
\hline Tinggi & 52 & 100,0 & 14 & 66,7 & 0,645 \\
\hline Sedang & 0 & 0 & 5 & 23,8 & \\
\hline Rendah & 0 & 0 & 2 & 9,5 & \\
\hline \multicolumn{6}{|l|}{ Sosial dan Budaya (Y2.3) } \\
\hline Tinggi & 40 & 76,9 & 12 & 57,1 & $0,032^{*}$ \\
\hline Sedang & 12 & 23,1 & 7 & 33,3 & \\
\hline Rendah & 0 & 0 & 2 & 9,5 & \\
\hline \multicolumn{6}{|c|}{ Tingkat pengelolaan hutan nagari secara berkelanjutan keseluruhan (Y2) } \\
\hline Tinggi & 44 & 84,6 & 11 & 52,4 & $0,018^{*}$ \\
\hline Sedang & 8 & 15,4 & 8 & 38,1 & \\
\hline Rendah & 0 & 0 & 2 & 9,5 & \\
\hline Jumlah & 52 & 100,0 & 21 & 100,0 & \\
\hline
\end{tabular}


malam hari, menjadi lebih aktif dengan kegiatan pengelolaan. Mereka juga diberikan tugas yang juga dapat menambah pendapatan seperti menjadi tour guide dalam pengelolaan pariwisata di Sungai Buluh. Di LPHN Paru, dengan adanya Hutan Nagari dapat mengubah kebiasaan masyarakat dalam pengelolaan hutan. Selain itu, sejalan dengan Guniastuti et al., (2014) yang menyebutkan bahwa salah satu dampak PHBM adalah meningkatnya pengakuan dan eksistensi masyarakat yang selama ini terpinggirkan, Hutan Nagari di Paru juga dapat mendorong kerja sama dari seluruh kalangan masyarakat tanpa adanya perbedaan status sosial.

Ditinjau dari aspek kebudayaan, dampak keberadaan Hutan Nagari adalah tetap terpeliharanya peraturan adat setempat sehubungan dengan pengelolaan Hutan Nagari baik di Sungai Buluh maupun di Paru. Hal ini sejalan dengan apa yang disampaikan oleh Lynch dan Harwell (2006) bahwa banyak prinsip legal dan ritual berbasis masyarakat menjadi prinsip penting dalam berbagai bentuk pengelolaan hutan berbasis masyarakat. Di Sungai Buluh, prinsip-prinsip adat dan tradisional tersebut salah satunya dengan terpeliharanya 'lubuk larangan' yang merupakan bentuk kearifan lokal masyarakat dalam pengelolaan ikan di mana pengambilan ikannya dibatasi selama kurun waktu tertentu atas dasar kesepakatan bersama masyarakat setempat. Ikan-ikan yang terdapat di sungai Hutan Nagari Sungai Buluh tersebut merupakan spesies dari ikan garing (Tor douronensis) yang berdasarkan peraturan adat dapat dipanen tiga tahun sekali. Keberadaan kearifan lokal ini turut membantu kelestarian alam dengan tidak hanya menjaga sumberdaya air tempat ikan tersebut hidup, akan tetapi juga menjaga spesies ikan lokal yang apabila tidak dikelola dengan benar, maka tentu akan musnah begitu saja. Sementara itu, kearifan lokal yang terdapat di Paru dalam hubungannya dengan pengelolaan Hutan Nagari yang juga dihubungkan dengan aspek sosial adalah secara adat istiadat, durian yang dapat diambil di kawasan Hutan Nagari Paru adalah durian yang sudah jatuh dari pohonnya. Siapapun yang mendapatkannya boleh mengambil durian tersebut karena dianggap sudah menjadi rejekinya.

Aspek ekonomi di kedua wilayah berada pada kategori sedang. Sejalan dengan Guniastuti et al., (2014) bahwa meskipun program PHBM berdampak pada pendapatan rata-rata anggota masyarakat pengelola tetapi belum mampu meningkatkan taraf hidupnya. Keberadaan Hutan Nagari di Sungai Buluh dan Paru belum dapat memberikan pengaruh besar dalam bidang ekonomi anggota masyarakat pengelola. Namun, tidak disangkal bahwa keberadaan Hutan Nagari di kedua wilayah dapat menambah lapangan pekerjaan masyarakat dan meningkatkan pendapatan, meskipun tidak terlalu banyak. Di Sungai Buluh misalnya, penambahan jenis lapangan pekerjaan dilihat dari pengolahan jamur tiram oleh beberapa anggota LPHN, beralih-fungsinya rumah-rumah warga menjadi home stay atau penginapan sementara ketika ada tamu-tamu nagari yang berasal dari luar daerah untuk menghadiri acara bersama Hutan Nagari, dan beralihnya profesi pemuda nagari menjadi tour guide untuk tempat-tempat wisata di sekitar Hutan Nagari Sungai Buluh.

\section{Hubungan Karakteristik Individu, Komunikasi Partisipatif dan Tingkat Dukungan dengan Tingkat Partisipasi dalam Pengelolaan Hutan Nagari}

Tidak terdapat hubungan pada taraf nyata $\mathrm{p}<0,05$ antara karakteristik individu dengan tingkat partisipasi dalam pengelolaan Hutan Nagari di LPHN Sungai Buluh (Tabel 6). Hal ini berarti bahwa partisipasi anggota masyarakat pengelola dalam mengelola Hutan Nagari di LPHN Sungai Buluh tidak tergantung pada karakteristik individu seperti umur, tingkat pendidikan formal, jenis kelamin, jenis pekerjaan, dan proporsi pendapatannya dari hutan, seperti yang juga disebutkan oleh Sadono et al., (2014) dan Susanty (2013). Baik anggota dengan usia muda, dewasa, tua maupun anggota dengan pendidikan rendah, sedang, tinggi tidak berbeda keterlibatannya dalam diskusi. Berdasarkan observasi di lapangan, ketua LPHN Sungai Buluh yang memiliki usia lebih muda (33 tahun) dan pendidikan yang lebih rendah (SMA) tetap lebih didengar dan dihormati suara dan keputusannya dibandingkan sekretaris LPHN Sungai Buluh yang berusia (36 tahun) dan berpendidikan tinggi (S1). Hal ini menegaskan bahwa, semua pihak dapat ikut dan berpartisipasi aktif dalam pengelolaan Hutan Nagari.

Sebaliknya, di LPHN Paru jenis kelamin berhubungan dengan tingkat partisipasi dalam pengelolaan Hutan Nagari. Artinya, terdapat hubungan antara jenis kelamin dengan tingkat partisipasi mereka dalam pengelolaan Hutan Nagari pada $p<0,05$ di mana diketahui bahwa laki-laki lebih sering berpartisipasi 
Tabel 6. Nilai Koefisien Korelasi chi Square antara Karakteristik Individu dengan Tingkat Partisipasi dalam Pengelolaan Hutan Nagari di LPHN Sungai Buluh dan Paru Sumatera Barat, 2016

\begin{tabular}{|c|c|c|c|}
\hline & \multirow{3}{*}{ Karakteristik Individu } & \multirow{2}{*}{\multicolumn{2}{|c|}{$\begin{array}{c}\text { Tingkat } \\
\text { Partisipasi dalam } \\
\text { Pengelolaan } \\
\text { Hutan Nagari } \\
\text { P-value }\end{array}$}} \\
\hline & & & \\
\hline & & $\begin{array}{l}\text { Sungai } \\
\text { Buluh }\end{array}$ & Paru \\
\hline 1. & Umur & 0,839 & 0,052 \\
\hline 2. & Tingkat pendidikan formal & 0,690 & 0,137 \\
\hline 3. & Jenis kelamin & 0,482 & $0,016^{*}$ \\
\hline 4. & Jenis pekerjaan & 0,081 & 0,162 \\
\hline 5. & $\begin{array}{l}\text { Proporsi pendapatan dari } \\
\text { hutan }\end{array}$ & 0,850 & 0,362 \\
\hline
\end{tabular}

dibanding wanita, seperti yang juga dikemukakan oleh Wibowo et al., (2012) dalam kasus usahatani. Menurut ketua LPHN Paru, perbedaan partisipasi antara lakilaki dan perempuan disebabkan oleh masih adanya pandangan bahwa pengambil keputusan merupakan tugas laki-laki, meskipun tidak menutup kemungkinan perempuan untuk memberikan pendapatnya.

Berdasarkan analisa rank Spearman pada Tabel 7 terdapat hubungan nyata pada taraf nyata $\mathrm{p}<0,05$ antara komunikasi partisipatif dengan tingkat partisipasi dalam pengelolaan Hutan Nagari di LPHN Sungai Buluhdan LPHN Paru. Hal tersebut menunjukkan bahwa di LPHN Sungai Buluh dan LPHN Paru komunikasi partisipatif berhubungan dengan keikutsertaan masyarakat anggota dalam mengelola Hutan Nagari. Hal ini sejalan dengan Warnock et al., (2007), bahwa ketika komunikasi partisipatif digunakan dengan benar untuk menerima aspirasi masyarakat lokal, maka peluang pengelolaan sumberdaya alam secara berkelanjutan menjadi lebih besar, termasuk dalam bidang pengelolaan hutan. Keikutsertaananggota masyarakat di LPHN Sungai Buluh dalam proses komunikasi telah meningkatkan pengelolaan Hutan Nagari sehingga menjadi lebih baik yang dibuktikan dengan keaktifan anggota berdialog dan menyuarakan pendapat dalam menyampaikan aspirasi dengan kesadaran mereka sendiri karena keinginan untuk keberlanjutan Hutan Nagari serta selalu dilakukannya refleksi-aksi baik pada pertemuan
Tabel 7. Nilai Koefisien Korelasi antara Komunikasi Partisipatf dan Tingkat Dukungan dengan Tingkat Partisipasi dalam Pengelolaan Hutan Nagari di LPHN Sungai Buluh dan Paru Sumatera Barat, 2016

\begin{tabular}{|c|c|c|c|c|c|}
\hline & \multirow{3}{*}{ Peubah } & \multicolumn{4}{|c|}{$\begin{array}{l}\text { Tingkat Partisipasi dalam } \\
\text { Pengelolaan Hutan Nagari }\end{array}$} \\
\hline & & \multicolumn{2}{|c|}{$\begin{array}{l}\text { LPHN Sungai } \\
\text { Buluh }\end{array}$} & \multicolumn{2}{|c|}{ LPHN Paru } \\
\hline & & $\mathbf{r}$ & $\begin{array}{l}\text { Sig. (2- } \\
\text { tailed) }\end{array}$ & $\mathbf{r}$ & $\begin{array}{l}\text { Sig. (2- } \\
\text { tailed) }\end{array}$ \\
\hline 1. & $\begin{array}{l}\text { Komunikasi } \\
\text { partisipatif }\end{array}$ & $0,431^{* *}$ & 0,001 & $0,551^{* *}$ & 0,010 \\
\hline 2. & $\begin{array}{l}\text { Tingkat } \\
\text { dukungan }\end{array}$ & $0,274^{*}$ & 0,050 & $0,646^{* *}$ & 0,002 \\
\hline
\end{tabular}

rutin bulanan maupun pertemuan untuk membahas kegiatan-kegiatan khusus, mampu mengantarkan Hutan Nagari Sungai Buluh menjadi Hutan Nagari model yang banyak ditiru cara pengelolaannya oleh seluruh pelaku hutan berbasis masyarakat di Sumatera Barat, baik HKm maupun HN.

Dukungan dalam pengelolaan Hutan Nagari terdiri atas bantuan biasanya diberikan oleh lembagalembaga pemerintahan ataupun non pemerintahan baik pada tingkat nagari, kecamatan, kota atau pun provinsi. Berdasarkan Tabel 7, terdapat hubungan pada taraf nyata $p<0,05$ antara tingkat dukungan dengan tingkat partisipasi dalam pengelolaan Hutan Nagari di LPHN Sungai Buluh dan LPHN Paru. Dukungan berupa pelatihan, dana, atau sumberdaya lainnya di LPHN Sungai Buluh mampu meningkatkan partisipasi masyarakat anggota dalam mengelola Hutan Nagari. Keterlibatan anggota dalam pelatihan budidaya jamur tiram yang diadakan oleh Dinas Kehutanan Provinsi Sumatera Barat misalnya, dapat mendorong anggota untuk lebih berpartisipasi aktif dalam kegiatan pengelolaan, meskipun sebagian besar sebatas tahap pelaksanaan kegiatan. Sebaliknya, keterbatasan fasilitas dan sumberdaya di LPHN Paru menyebabkan masyarakat anggota pengelola menjadi lebih enggan dalam berpartisipasi, sehingga keterlibatan masyarakat anggota dalam aktivitas pengelolaan juga menjadi rendah.

Hal ini menunjukkan bahwa baik di LPHN Sungai Buluh maupun di LPHN Paru, tingkat dukungan berhubungan dengan tingkat partisipasi 
masyarakat anggota dalam pengelolaan Hutan Nagari, sebab dukungan penuh dari berbagai pihak untuk mengembangkan LPHN di kedua wilayah tersebut masih sangat diperlukan, mengingat bahwa kedua LPHN tersebut masih baru berdiri sehingga sangat memerlukan bantuan dari pihak lain, seperti pemerintah, tokoh nagari, serta sumberdaya lainnya. Hal tersebut sejalan dengan Wilujeng (2015) bahwa salah satu faktor pendukung keberhasilan implementasi program PHBM, termasuk Hutan Nagari, adalah tercukupinya sumberdaya dan fasilitas sarana prasarana. Berdasarkan hal itu, dengan adanya dukungan penuh dari berbagai pihak dari berbagai aspek termasuk sumberdaya dan sarana prasarana, partisipasi anggota masyarakat pengelola Hutan Nagari menjadi meningkat.

\section{Hubungan Tingkat Partisipasi dalam Pengelolaan Hutan Nagari dengan Tingkat Pengelolaan Hutan Nagari Secara Berkelanjutan}

Terdapat hubungan nyata pada taraf nyata $\mathrm{p}<0,1$ antara tingkat partisipasi dalam pengelolaan Hutan Nagari dengan tingkat pengelolaan Hutan Nagari secara berkelanjutan di LPHN Sungai Buluh dan LPHN Paru (Tabel 8). Pengelolaan Hutan Nagari di Sungai Buluh baik pada aspek perencanaan, penetapan batas areal kerja, pelaksanaan kegiatan mapun monitoring dan evaluasi, dapatmendorong atau mengurangi tingkat pengelolaan Hutan Nagari secara berkelanjutan.

Menurut responden dan pengamatan di lapangan, partisipasi anggota masyarakat pengelola dalam pengelolaan Hutan Nagari di Nagari Sungai
Buluh berlangsung kurang maksimal, terutama pada aspek penetapan batas areal kerja dan monitoring evaluasi. Akan tetapi, anggota masyarakat pengelola Hutan Nagari tetap mampu mengelola hutan secara berkelanjutan dengan baik. Hal ini ditunjukkan dengan partisipasi anggota masyarakat pengelola terutama pada aspek pelaksanaan kegiatan yang diperlihatkan dengan kesadaran masyarakat dalam menjaga dan memelihara Hutan Nagari serta keterbukaan mereka dalam menerima informasi dan solusi atas masalah yang dihadapi sertamenjalankan kegiatan pengelolaan Hutan Nagari beriringan dengan peraturan adat yang memang sudah mendukung pengelolaan Hutan Nagari secara lestari, bahkan sebelum dibentuknya Hutan Nagari. Anggota masyarakat pengelola diakui haknya pada keikutertaan mereka dalam mengelola Hutan Nagari, selain juga harus mengingat kewajiban untuk tetap memelihara dan menjaga Hutan Nagari. Hal ini sejalan dengan yang dikemukakan oleh Salampessy et al., (2010) bahwa hak individu yang diperoleh dan diakui serta diberikan tanggung jawab dapat membantu mengamankan dan menjaga kondisi sumberdata hutan agar tetap terjaga.

Tabel 8 memperlihatkan bahwa di LPHN Paru terdapat hubungan nyata pada taraf $p<0,1$ antara tingkat partisipasi dalam pengelolaan hutan dengan tingkat pengelolaan Hutan Nagari secara berkelanjutan. Berdasarkan observasi di lapangan, rendahnya partisipasi masyarakat dalam pengelolaan Hutan Nagari ikut menurunkan pengelolaan hutan secara berkelanjutan di Nagari Paru. Pada aspek ekonomi, salah satunya terlihat darikurang terlibatnya masyarakat anggota LPHN Paru dalam mengikuti kegiatan-

Tabel 8. Nilai Koefisien Korelasi Tingkat Partisipasi dalam Pengelolaan Hutan Nagari dengan Tingkat Pengelolaan Hutan Nagari Secara Berkelanjutan di LPHN Sungai Buluh dan Paru Sumatera Barat, 2016

\begin{tabular}{|c|c|c|c|c|c|c|}
\hline \multirow{3}{*}{ Peubah } & \multicolumn{3}{|c|}{ LPHN Sungai Buluh } & \multicolumn{3}{|c|}{ LPHN Paru } \\
\hline & Ekonomi & Ekologi & Sos-Bud & Ekonomi & Ekologi & Sos-Bud \\
\hline & $\mathbf{r}$ & $\mathbf{r}$ & $\mathbf{r}$ & $\mathbf{r}$ & $\mathbf{r}$ & $\mathbf{r}$ \\
\hline $\begin{array}{l}\text { Tingkat partisipasi dalam pengelolaan } \\
\text { Hutan Nagari (total) }\end{array}$ & \multicolumn{2}{|c|}{$0,521^{*}$} & \multicolumn{4}{|c|}{$0,568^{*}$} \\
\hline 1. Perencanaan & $-0,150$ & 0,084 & 0,045 & $0,368^{*}$ & 0,223 & 0,250 \\
\hline 2. Penetapan batas areal kerja & $-0,190$ & $0,353^{*}$ & 0,262 & $0,418^{*}$ & 0,176 & 0,211 \\
\hline 3. Pelaksanaan kegiatan & 0,062 & 0,175 & 0,233 & $0,698^{* *}$ & $0,455^{*}$ & $0,485^{*}$ \\
\hline 4. Monitoring evaluasi & $-0,081$ & 0,247 & 0,184 & $0,414^{*}$ & 0,215 & 0,213 \\
\hline
\end{tabular}


kegiatan pelatihan terutama sehubungan dengan pengembangan kemampuan untuk diversifikasi jenis pekerjaan yang diadakan oleh dinas provinsi, sehingga kemampuan masyarakat dalam meningkatkan soft skill yang dapat meningkatkan taraf pendapatan dan perekonomian menjadi lebih rendah.

Padahal untuk mendorong pengelolaan Hutan Nagari secara berkelanjutan juga diperlukan partisipasi seluruh anggota masyarakat pengelola dalam setiap aspek pengelolaan mulai dari perencanaan, penetapan batas areal kerja, pelaksanaan kegiatan, hingga monitoring dan evaluasi. Hal ini memperlihatkan bahwa seperti yang diungkapkan oleh Gunawan et al., (2014) di mana keterlibatan yang pasif dari anggota masyarakat pengelola menyebabkan kurang maksimalnya implementasi program PHBM, kurangnya keikutsertaan anggota masyarakat pengelola LPHN Paru dalam kegiatan pengelolaan Hutan Nagari juga menyebabkan turunnya tingkat pengelolaan Hutan Nagari secara lestari di Nagari Paru.

\section{Kesimpulan}

Anggota masyarakat pengelola di Hutan Nagari Sungai Buluh cukup berpartisipasi dalam pengelolaan Hutan Nagari, sedangkan di Hutan Nagari Paru kurang berpartisipasi. Kurangnya keterlibatan anggota masyarakat dalam pengelolaan Hutan Nagari terjadi karena anggota masyarakat kurang dilibatkan dalam kegiatan pengelolaan yang terdiri atas kegiatan perencanaan, penetapan batas areal kerja, dan monitoring dan evaluasi. Hal ini harus diminimalisir dengan melibatkan seluruh anggota masyarakat pengelola dalam setiap aktivitas pengelolaan, serta memberikan kepercayaan kepada anggota untuk dapat merefleksikan aksinya pada tindakan kolektif melalui pelaksanaan kegiatan bersama.

Pengelolaan Hutan Nagari di LPHN Sungai BuluhdanLPHNParusudahberkelanjutan. Secaraumum, pengelolaan Hutan Nagari didukung oleh komunikasi yang partisipatif; tingginya dukungan pemerintah, dukungan tokoh, dan bantuan berupa sumberdaya; dan partisipasi anggota masyarakat yang kuat. Berbeda dengan pengelolaan Hutan Nagari di LPHN Sungai Buluh, pengelolaan Hutan Nagari di LPHN Paru diperkuat dengan adanya dukungan-dukungan yang diberikan oleh pemerintah, tokoh nagari, serta sumberdaya.

\section{Daftar Pustaka}

Anomsari ET. 2013. Partisipasi Masyarakat dalam Pengelolaan Hutan Bersama Masyarakat. Jurnal Natapraja1 (1) : 75-91.

[CIFOR] Center for International Forestry Research. 2015. Kabar Hutan. [internet]. [blog.CIFOR.org].

Damayatanti PT. 2011. Upaya Pelestarian Hutan Melalui Pengelolaan Sumberdaya Hutan Bersama Masyarakat. Jurnal Komunitas 2 (1): 70-82.

Flor AG. 2004. Environmental Communication: Principles, Approaches and Strategies of Communication Applied to Environmental Communication. Philippines (PH): UP Open University.

Gunawan KS, Barkey RA, Hajar MAI. 2014. Implementasi Program Pengelolaan Sumberdaya Hutan Bersama Masyarakat dalam Perspektif Pemberdayaan Desa Hutan. E-Jurnal Digitalisasi Perpustakaan Pusat UNHAS. [internet]. [dapat diunduh di pasca.unhas.ac.id/jurnal/files/].

Guniastuti D, Jusuf Y, Bulkis S. 2014. Peran Program Pengelolaan Hutan Bersama Masyarakat di Kesatauan Pemangkuan Hutan (KPH) Kendal Terhadap Kesejahteraan Masyarakat. E-Jurnal Digitalisasi Perpustakaan Pusat UNHAS. [internet] [dapat diunduh di https://repository. unhas.ac.id:4001/digilib/]

Godemann J, Michelsen G. 2011. Sustainability Communication, Interdiciplinary Perspectives and Theoritical Foundations. London (UK): Springer.

Harris JM. 2000. Basic Principles of Sustainable Development. Global Development and Environment Working Paper. 00-04: 1-24. Medford (US): Tufts University.

Hendri E, Purnaningsih N, Saleh A. 2014. Analisis Efektivitas Musyawarah Perencanaan Pembangunan. Jurnal Komunikasi Pembangunan12 (2) : 60-79.

Kusumadinata AA, Sarwoprasodjo S, Purnaningsih N. 2012. Analisis Komunikasi Partisipasi dalam Penyelenggaraan Program Perbaikan Gizi Masyarakat (Studi Kasus pada Kelompok Gizi Masyarakat Pulokerto Kota Palembang). Jurnal Komunikasi Pembangunan 10 (2): 30-42.

Lynch OJ, Harwell E. 2006. Sumberdaya Milik Siapa? Siapa Penguasa Barang Publik? Bogor (ID): Studio Kendil. 
Muchtar K, Purnaningsih N, Susanto D. 2014. Komunikasi Partisipatif pada Sekolah Lapangan Pengelolaan Tanaman Terpadu (SL-PTT). Jurnal Komunikasi Pembangunan 12 (2) : 1-14.

Muslikhah FP. 2015. Komunikasi Partisipatif pada Kelompok Wanita Tani di KecamatanKajuran Kabupaten Magelang. [tesis]. Bogor (ID) : IPB.

Nandini R. 2013. Evaluasi Pengelolaan Hutan Kemasyarakatan ( $\mathrm{Hkm}$ ) pada Hutan Produksi dan Hutan Lindung di Pulau Lombok. Jurnal Penelitian Hutan Tanaman 10 (1) : 43-55.

Nasikh. 2009. Partisipasi Masyarakat pada Pengelolaan Hutan di Kawasan Gerakan Rehabilitasi Hutan dan Lahan (Gerhan) Pasuruan Jawa Timur. Jurnal Masyarakat Kebudayaan dan Politik 22 (2): 33 - 45. Ngabdani M, Muryani C, Sudaryanto R. 2015. Partisipasi Masyarakat dalam Pelaksanaan Program Pengelolaan Hutan Bersama Masyarakat (PHBM) di Desa Girimulyo Kecamatan Jogorogo Kabupaten Ngawi. Jurnal GeoEco1 (1): 58-66.

Nugroho SS. 2011. Pengelolaan Hutan Bersama Masyarakat (PHBM) Melalui Penguatan Lembaga Masyarakat Desa Hutan (LMDH) (Kajian Hukum Penguatan Kapasitas LMDH dan Peningkatan Efektivitas PHBM di Desa Dampit, Kecamatan Bringin, Kabupaten Ngawi). Jurnal Sosial 12 (2): 94-107.

Peraturan Menteri Kehutanan Republik Indonesia. 2014. Hutan Desa. PerMenhut No: P.89/MenhutII/2014. Jakarta (ID).

Peraturan Nagari Sungai Buluh Nomor: 08 Tahun 2012 Tentang Lembaga Pengelolaan Hutan Nagari.

Purwatinigsih SD, Dahlan S. 2015. Communication Strategy for Better Understanding Community on Conservation Forest at National Park Halimun Salak. International Journal of Business and Social Science 6 (2): 107-112.

Riana, Purnaningsih N, SatriaA. 2015. Peranan Penyuluh Swadaya dalam Mendukung Intensifikasi Kakao di Kabupaten Sigi Provinsi Sulawesi Tengah. Jurnal Penyuluhan 11 (2): 201 - 211.

Sadono D, Sumardjo, Gani DS, Amanah S. 2014.

Farmer Empowerment in The Management of Rice Farming in Two Districts in West Java. Journal of Rural Indonesia 2 (1): 105 - 126.

Salampessy ML, Nugroho B, Purnomo H. 2010. Partisipasi Kelompok Masyarakat dalam Pengelolaan Hutan Lindung, Kasus di Hutan Lindung Gunung Nona Kota Ambon Propinsi Maluku. Jurnal Parennial 6(2): 99-107.
Santoso H. 2011. Hutan Kemasyarakatan dan Hutan Desa: Tafsir Setengah Hati Pengelolaan Hutan Berbasis Masyarakat Versi Kementrian Kehutanan RI. Jurnal Kehutanan Masyarakat 3(1) : 52-78.

Satriani I, Muljono P, Lumintang RWE. 2011. Komunikasi Partisipatif Pada Program Pos Pemberdayaan Keluarga (Studi Kasus di RW 05 Kelurahan Situgede, Kecamatan Bogor Barat, Kota Bogor). Jurnal Komunikasi Pembangunan 9 (2): 17-27.

Sevaes J. 2011. Communication for Sustainable Development; Indicators for Impact Assessment in USAID Project "Educational Reform in the Classroom in Guatemala". Journal of Latin American Communication Research 2 (2): 3-34.

Sumardjo. 2012. Review dan Refleksi Model Penyuluhan dan Inovasi Penyuluhan Masa Depan. Makalah pada Seminar Nasional membangun Masa Depan yang Berkeadilan dan Menyejahterakan, 22 Februari 2012. Bogor: Program Pascasarjana PPN IPB dan PAPPI.

Suprayitno AR. 2008. Pelibatan Masyarakat Lokal: Upaya Memberdayakan Masyarakat Menuju Hutan Lestari. Jurnal Penyuluhan 4 (2) : 135 - 138. 2011. Model Peningkatan Partisipasi Petani Sekitar Hutan dalam Mengelola Hutan Kemiri Rakyat (Kasus Pengelolaan Hutan Kemiri Kawasan Pegunungan Bulusarung Kabupaten Maros Provinsi Sulawesi Selatan). [disertasi]. Bogor (ID): IPB.

Susanti E. 2013. Tingkat Pemberdayaan Perempuan Kepala Keluarga (Kasus di Desa Dayah Tanoh Kecamatan Mutiara Timur Kabupaten Pidie Provinsi Aceh). Jurnal Agrisep14 (2) : 44-53.

Susanty P. 2013. Komunikasi Partisipatif pada Pelaksanaan Program Pendidikan Lingkungan Hidup Green School di Kecamatan Cicurug Kabupaten Sukabumi. [thesis]. Bogor (ID) : IPB.

Sutejo P. 2014. Hubungan Progam Pengelolaan Hutan Bersama Masyarakat terhadap Peningkatan Pendapatan Masyarakat. Jurnal Ilmiah Pendidikan Geografi 2 (1): 39-48.

Steurer R, Langer ME, Konrad A, Martinuzzi A. 2005. Corporations, Stakeholders and Sustainable Development I: A Theoretical Exploration of Business-Society Relations. Journal of Business Ethics. Springer 61: 263-281.

United Nations. 2015. Sustainable Development Goals. [internet]. [https://sustainabledevelopment. un.org/topics] 
Utama S. 2010. Dinamika Kelompok Tani Hutan pada Pengelolaan Hutan Produksi Bersama Masyarakat di Perum Perhutani Unit I Provinsi Jawa Tengah. Jurnal Penyuluhan 6 (1) : 49 - 64.

[WCCD] World Congress on Communication for Development. 2006. Communication For Sustainable Development; FAO Communication For Development Group. FAO.

Wibowo CT, Sumardjo, Hafidhuddin D, Agung SS. 2012. Pola Komunikasi pada Pengembangan Kapasitas Kewirausahaan Petani Sayuran (Kasus Pendampingan Misi Teknik Taiwan di Kabupaten Boyolali dan Bogor). Jurnal Komunikasi Pembangunan 10 (1): 47-57.

Wilujeng E. 2015. Implementasi Kebijakan Pengelolaan Hutan Bersama Masyarakat (PHBM) Dalam Rangka Pelestarian Hutan di KPH Blora. Jurnal
Kebijakan dan Manajemen Publik 3 (1) : 1-10.

Winata A, Yuliana E. 2012. Tingkat Partisipasi Petani Hutan dalam Program Pengelolaan Hutan Bersama Masyarakat (PHBM) Perhutani. Jurnal Mimbar 28 (1) : $65-76$.

Wiyonoputri JO. 2014. Pemberdayaan Masyarakat Melalui Program Pengelolaan Hutan Bersama Masyarakat Sebagai Upaya Peningkatan Pendapatan Masyarakat Desa Hutan (Studi Pada Lembaga Masyarakat Desa Hutan Podang Wilis Desa Durenan Kecamatan Gemarang Kabupaten Madiun). Jurnal Admininstrasi Publik 2 (7): abstrak. Zainal M, Lubis DP, Rangkuti PA. 2014. Pola Komunikasi Partisipatif pada Program Pengembangan Usaha Agribisnis Perdesaan di Kabupaten Bogor. Jurnal Komunikasi Pembangunan. 12 (2): 80-90. 